Tropical Bryology 25: 7-17, 2004

\title{
Additions to the Bryophyte Flora of the Neotropics
}

\author{
Michael Lüth ${ }^{1}$ \& Alfons Schäfer-Verwimp² \\ ${ }^{1}$ Emmendinger Str. 32, D-79106 Freiburg, Germany. \\ ${ }^{2}$ Mittlere Letten 11, D-88634 Herdwangen-Schönach, Germany.
}

\begin{abstract}
New and remarkable records of bryophytes from Venezuela, Brazil, Costa Rica and Ecuador are reported. Diphyscium chiapense and Hedwigia ciliata var. leucophaea are new to South America. New to Venezuela are Grimmia reflexidens, Metzgeria claviflora, Pilopogon peruvianus and Racomitrium subsecundum; Grimmia navicularis and G. trichophylla are firstly reported for Brazil; Aphanolejeunea microscopica var. africana, A. minuta, A. sintenisii, Cololejeunea bischleriana, Metalejeunea cucullata, and Hyophila nymaniana represent new records for Costa Rica, and new to Ecuador are Diphyscium longifolium, Erpodium beccarii, Macrocolura sagittistipula, and (for continental Ecuador) Marchantia berteroana. Further new records to the states of that countries and rarely collected species are listed. All specimens are deposited in the private herbaria of the authors, duplicates in different herbaria as indicated.
\end{abstract}

\section{VENEZUELA}

\section{Calymperes nicaraguense Ren. \& Card.}

Estado Barinas: W-Llanos, Reserva Forestales Caparo, semi-deciduos forest, epiphytic on trunk of big tree, $140 \mathrm{~m}, 18.3 .2001$, leg. M. Lüth 3325.

Distr.: West Indies, and from Mexico to Bolivia and Brazil. An apparently rare species, from Venezuela cited only from Bolivar (Reese 1993).

\section{Campylopus cuspidatus (Hornsch.) Mitt.}

Estado Mérida: Sierra Nevada, Páramo at Laguna Mucubaji, occasional at the shore of the lake and plenty in a swampy hollow on the trail to Laguna Negra, together with Campylopus argyrocaulon (C. Müll.) Broth. and Breutelia subarcuata (C. Müll.) Schimp. ex Besch., 3700 m, 14.3.2001, leg. M. Lüth 3253, det. J.-P. Frahm.

Distr.: Disjunct in Mexico, Costa Rica, Guatemala, Venezuela and SE Brazil. Second record for Venezuela. There are unpublished collections of this species from the same greater area made by J.-P. Frahm and by M. Infante \& P. Heras (pers. comm. from J.-P. Frahm).

\section{Diphyscium chiapense Norris}

Estado Aragua: Cordillera de la Costa, P. N. Henry Pittier, Botanical Station Rancho Grande, trail to Pico Guacamaya, cloud forest near the peak, on a shady gneis boulder, $1700 \mathrm{~m}, 24.3 .2001$, leg M. Lüth 3353.

Distr.: Known only from Mexico and Costa Rica (Magombo 2003); new to South America. 


\section{Grimmia elongata Kaulf. in Sturm}

Estado Mérida: Sierra Nevada, Pico Espejo near Mérida city, on exposed rock, 4765 m, 19.1.1990, leg. Schäfer-Verwimp \& Verwimp 12280a, det. J. Muñoz (MA only); -, -, Estacion Loma Redonda, Páramo, on sunny gneis rock, 4100 m, 15.3.2001, leg. M. Lüth 3265, det. E. Maier (G).

Distr.: Europe, Asia, northern and southern America; first and second record for Venezuela. The records given in Muñoz \& Pando (2000) as well as in Churchill et al. (2000) refer to the first cited specimen above.

\section{Grimmia fuscolutea Hook.}

Estado Mérida: Sierra Nevada, Páramo near Aguila Pass, on sunny rocks along the road, 4100 m, 14.3.2001, leg. M. Lüth 3228; Sierra Nevada, cable car to Pico Espejo, last station on the top, alpine vegetation, $\mathrm{N}$-exposed steep slope near station, on shady rock, $4800 \mathrm{~m}, 15.3 .2001$, leg. M. Lüth 3273; -, -, on exposed rock, 4765 m, 19.1.1990, leg. Schäfer-Verwimp \& Verwimp 12280, det. J. Muñoz \& E. Maier (FLAS).

Distr.: Europe, Africa, Asia, Antarctica, America (Muñoz \& Pando 2000). Rarely collected in Venezuela.

\section{Grimmia reflexidens Müll. Hal.}

Estado Mérida: Sierra Nevada, cable car to Pico Espejo, last station near the top, alpine vegetation, on vertical surface of sunny, Sexposed rock near station, $4800 \mathrm{~m}, 15.3 .2001$, leg. M. Lüth 3280, conf. E. Maier as G. sessitana De Not (synonymized by Muñoz 1999).

Distr.: Europe, Africa, Asia, Australasia, Antarctica, northern and southern America. New to Venezuela.

\section{Hedwigia ciliata var. leucophaea Bruch \& Schimp.}

Estado Mérida: Sierra Nevada, road Valera - Aguila Pass, block field in Páramo near Aguila Pass, on sunny boulder, 3900 m, 14.3.2001, leg. M. Lüth 3245; Sierra Nevada, Laguna Coromoto, Subpáramo, on a sunny boulder, 3000 m, 16.3.2001, leg. M. Lüth 3304.

Note: Hedwigia ciliata var. leucophaea is characterized by a long hyaline and papillose leaf apex (22-55\% of the leaf length, Hedenäs 1994), that is pure white and strongly contrasted by the rest of the leaf and leaf margins sometimes recurved below and plane above. All Hedwigia, that have been collected hitherto in Latin America belong to $H$. nivalis (M. Müll.) Mitt. (Allen, in prep.), which also can have a long hyaline leaf apex. The type of $H$. nivalis comes from the same area, Merida in Venezuela (Buck \& Norris 1996) where $H$. ciliata var. leucophaea now was collected two times. $H$. nivalis differs from the latter taxon by the presence of incurved upper leaf margins, while those of $H$. ciliata var. leucophaea are plane (Allen, in prep.).

Distr.: Europe, western North America; new to Latin America.

\section{Metzgeria claviflora Spruce}

Estado Mérida: Sierra Nevada, trail to Laguna Coromoto, cloud forest, on a rotting log, 2550 m, 16.3.2001, leg. M. Lüth 3309.

Distr.: Hitherto known from the West Indies, Nicaragua, and Ecuador (Kuwahara 1986). New to Venezuela.

\section{Pilopogon peruvianus (Williams) Frahm}

Estado Mérida: Sierra Nevada, cable car to Pico Espejo, Estacion Loma Redonda, Páramo, on sunny gneis rock near the cable car station, 4100 m, 15.3.2001, leg. M. Lüth 3262, conf. J.-P. Frahm.

Distr.: Hitherto known only from Ecuador and Peru (Frahm 1991: 215). First record for Venezuela.

\section{Racomitrium subsecundum (Harv.) Wils. in Mitt. \& Wils.}

Estado Mérida: Sierra Nevada, cable car to Pico Espejo, last station on the top, alpine vegetation, $\mathrm{N}$-exposed steep slope near station, on shady humid rock, $4800 \mathrm{~m}, 15.3 .2001$, leg. M. Lüth 3272 \& 3276, det. H. Bednarek-Ochyra; Sierra Nevada, trail to Laguna Coromoto, cloud forest, on a big, open boulder in a brook, growing above the water line, $2450 \mathrm{~m}, 16.3 .2001$, leg. M. Lüth 3290, det. H. Bednarek-Ochyra (KRAM).

Distr.: Pantropical taxa, recently reported for the first time in South America from Brazil, Colombia (Bednarek-Ochyra et al. 1999), Ecuador, 
and Bolivia (Bednarek-Ochyra 2001). First record for Venezuela.

Squamidium diversicoma (Hampe) Broth.

Estado Mérida: Sierra Nevada, at the begin of the trail to Laguna Coromoto, open, sunny boulders in a pasture, $1800 \mathrm{~m}, 16.3 .2001$, leg. M. Lüth 3206.

Distr.: From Mexico and Honduras to southeastern Brazil, from Venezuela mentioned from the states of Aragua and Lara (Allen \& Crosby 1986).

Squamidium isocladum (Ren. \& Card.) Broth.

Estado Mérida: Sierra Nevada, at the begin of the trail to Laguna Coromoto, open, sunny boulders in a pasture, $1800 \mathrm{~m}, 16.3 .2001$, leg. M. Lüth 3208.

Distr. : Central and South America, West Indies, only once recorded from Venezuela (Allen \& Crosby 1986).

\section{BRAZIL}

\section{Aphanolejeunea clavatopapillata (Steph.) Reiner}

Minas Gerais: Poços de Caldas, humid montane rain forest on Morro São Domingos, epiphyllous, c. spor., 1250-1450 m, 20.4.1991, leg. Schäfer-Verwimp \& Verwimp 14415/C. Rio de Janeiro: Serra de Itatiaia, rain forest near waterfall Veu da Noiva, epiphyllous, 1100 m, 9.7.1991, leg. Schäfer-Verwimp \& Verwimp 14670/B.

Distr.: Florida, Cuba, Costa Rica, Argentina, Paraguay; from Brazil known only from São Paulo; new to Minas Gerais and Rio de Janeiro.

\section{Breutelia microdonta (Mitt.) Broth.}

Santa Catarina: Santa Cecilia, Sphagnum bog on BR 116, 1140 m, 20.12.1988, leg. SchäferVerwimp \& Verwimp 10461; -, Serra do Rio do Rastro, Urubici, Morro da Igreja, N-exposed rocks near the radar station beside the peak, humid vertical rock surface, $1780 \mathrm{~m}, 17.9 .2001$, leg M. Lüth 3605.

Distr.: Longly known as endemic of SE Brazil until Griffin (1992) pointed out that this is a widespread tropical species and reported it also from Venezuela, Guadeloupe, Southern Africa, and the Philippines. New to Santa Catarina.

\section{Breutelia wainioi Broth.}

Rio de Janeiro: Serra da Mantiqueira, Itatiaia National Park, Agulhas Negras, trail to Pico Itatiaia, at a small spring with seeping water at the bottom of a slope beside the trail, $2550 \mathrm{~m}$, 27.9.2001, leg. M. Lüth 3652.

Distr.: Brazil, Bolivia, and Southern South America, as given in Churchill et al. (2000). From the state of Rio de Janeiro known only from very old Glaziou collections (Griffin 1984).

\section{Campylopus cryptopodioides Broth.}

Santa Catarina: Blumenau, Corubá, Morro da Igreja, peak with shrubs and small trees, epiphytic on a small horizontal branch of a tree, 860 m, 12.9.2001, leg. M. Lüth 3553, det. J.-P. Frahm.

Distr.: SE-Brazil and adjacent Argentina. New to Santa Catarina.

Campylopus cuspidatus (Hornsch.) Mitt. var. dicnemioides (Müll. Hal.) Frahm

Santa Catarina: Serra do Rio do Rastro, Urubici, Morro da Igreja, N-exposed rocks near the radar station beside the peak, humid ground between rocks, together with Dicranoloma billardieri (Brid.) Par. and Herbertus serratus Spruce, 1780 m, 17.9.2001, leg M. Lüth 3553; Rio de Janeiro: Serra da Mantiqueira, Itatiaia National Park, Agulhas Negras, trail to Pico Itatiaia, plants with plenty sporophytes at a small spring with seeping water at the bottom of a slope beside the trail, together with Breutelia wainioi Broth., 2550 m, 27.9.2001, leg. M. Lüth 3653.

Distr.: SE-Brazil, Venezuela, Colombia, Ecuador, Peru and Bolivia.

\section{Campylopus julaceus (Hampe) Jaeg.}

Rio Grande do Sul: Serra Gaucho, Gramado, Knorr-Park, on earth, 900 m, 19.1.1987, leg. Schäfer-Verwimp \& Verwimp 8197, det. Frahm (1987; hb. Frahm).

Distr.: Known from Bolivia, Argentina, Paraguay, and in Brazil from the Northeast to the South (Frahm 1991); new state record for Rio Grande do Sul. 
Campylopus reflexisetus (Müll. Hal.) Broth.

Santa Catarina: Blumenau, Corubá, valley of Ano Bom, big waterfall of Ano Bom, humid rock with soil, on the top of the waterfall, $520 \mathrm{~m}$, 10.9.2001, leg. M. Lüth 3533, det. J.-P. Frahm.

Distr.: Mexico, Costa Rica, Venezuela, Colombia, Ecuador, Peru, Bolivia and Brazil. Second record for Brazil, new to Santa Catarina.

\section{Campylopus sehnemii Bartram}

Santa Catarina: Serra do Rio do Rastro, Urubici, Morro da Igreja, N-exposed rocks near the radar station beside the peak, at the edge on top of the rocks, $1780 \mathrm{~m}, 17.9 .2001$, leg M. Lüth 3606, det. J.-P. Frahm.

Distr.: SE Brazil, just known from a few localities (Frahm 1991). New to Santa Catarina.

\section{Campylopus widgrenii (Müll. Hal.) Mitt.}

Santa Catarina: Serra do Rio do Rastro, Urubici, pass between Rancho Queimado and Alfredo Wagner, black small cushions on sunny vertical rock beside the street, $1050 \mathrm{~m}, 16.9 .2001$, leg. M. Lüth 3576, det. J.-P. Frahm.

Distr.: A rather rare species, known only from a few localities from NE and SE Brazil (Frahm 1991).

\section{Erpodium biseriatum (Aust.) Aust.}

Goias: Alto Paraiso, Chapada dos Veadeiros, forest on steep slope on Rio São Miguel, epiphytic, c. spor., 820 m, 21.7.1988, leg. Schäfer-Verwimp \& Verwimp 9854. São Paulo: Teodoro Sampaio (ca 700 km W of São Paulo City, primary forest on Morro do Diabo, epiphytic, c. spor., 500 m, 14.2.1988, leg. SchäferVerwimp \& Verwimp.

Distr.: Widespread but scattered in the tropics, known from the U.S.A., Mexico, West Indies, Venezuela, Paraguay, Brazil, Africa (Tanzania), India, Sri Lanka, Thailand, Indonesia, the Philippines, Taiwan, and Australia (Stone 1997). From Brazil known only from a very few collections from Paraná and São Paulo (Vital 1980, Yano 1995). New to Goias.
Grimmia laevigata (Brid.) Brid.

Rio Grande do Sul: Aparados da Serra, Cambara do Sul, pasture $\mathrm{S}$ of the village, plenty large cushions on sunny rocks and boulders, together with Campylopus introflexus (Hedw.) Brid., 1030 m, 19.9.2001, leg. M. Lüth 3617.

Distr.: Europe, Africa, Asia, Australasia, northern and southern America; in South America the occurrence of $G$. laevigata is confined to Argentina, Chile and South Brazil (Muñoz 1999).

\section{Grimmia navicularis Herz.}

Rio de Janeiro: Serra da Mantiqueira, Itatiaia National Park, Agulhas Negras, trail to Pico Itatiaia, on top of open sunny rock beside the trail, 2450 m, 27.9.2001, leg. M. Lüth 3648, det. C. Delgadillo (MEXU).

Distr.: Along the Andes from Venezuela to Patagonia (Muñoz 1999). First record for Brazil. There is another, unpublished collection of $G$. navicularis from Brazil (pers. comm. from C. Delgadillo): Serra do Itatiaia. In rupibus, 2200 m, P. Dusén s.n. 05/1902. (NY), det. C. Delgadillo.

\section{Grimmia trichophylla Grev.}

Santa Catarina: Serra do Rio do Rastro, Urubici, Morro da Igreja, sunny rock in pasture on the road to the radar station, $1550 \mathrm{~m}$, leg. M. Lüth 3581, and sunny rock near the radar station, 1780 m, 17.9.2001, leg. M. Lüth 3597, det. H. Greven, conf. J. Muñoz and C. Delgadillo (MA, MEXU, hb. Greven); Rio de Janeiro: Serra da Mantiqueira, Itatiaia National Park, Agulhas Negras, trail to Pico Itatiaia, on sunny boulder, 2430 m, 27.9.2001, leg. M. Lüth 3647, det. H. Greven, conf. J. Muñoz (MA, hb. Greven).

Distr.: Europe, Africa, Asia, Australasia, northern and southern America; in South America so far known only from the Andes from Venezuela to Tierra del Fuego (Muñoz 1999). New to Brazil.

\section{Herpetineuron toccoae (Sull. \& Lesq.) Card.}

Minas Gerais: Caldas, Pocinho do Rio Verde, rain forest on waterfall A. Moreiro, on humid rock, 1050 m, 25.5.1986, leg. SchäferVerwimp \& Verwimp 7042 (EGR, G, STU). Santa Catarina: Road BR 282 between Canoas and Bom Retiro, on rotting wood in humid forest, $850 \mathrm{~m}$, 
21.12.1988, leg. Schäfer-Verwimp \& Verwimp 10483, det. H. Crum (MICH).

Distr.: Pantropical but elsewhere scattered, from Brazil known from the states of Mato Grosso, Paraná, Rio de Janeiro, and São Paulo (Yano 1981); new to Minas Gerais and Santa Catarina.

\section{Holomitrium nitidum Herz.}

São Paulo: Ilha de São Sebastião, rain forest on central part of the island, epiphytic, 570 m, 9.2.1990, leg. Schäfer-Verwimp \& Verwimp 12434; -, Eldorado, Park „Caverna do Diabo“, Morro do Angico, cloud forest beneath the peak, epiphytic on a small horizontal branch, $600 \mathrm{~m}$, 31.8.2001, leg. M. Lüth 3438; Santa Catarina: Blumenau, Corubá, Morro da Igreja, peak with shrubs and small trees, together with $H$. crispulum Mart. epiphytic on a small horizontal branch of a tree, $860 \mathrm{~m}, 12.9 .2001$, leg. M. Lüth 3552, all det. M. Price.

Distr.: Known onyl from a few collections from SE Brazil, but probably overlooked or mistaken for H. crispulum (M. Price in litt.); new to Santa Catarina.

Hyophiladelphus agrarius (Hedw.) Zand. [= Barbula agraria Hedw.]

Amazonas: Manaus, Rua Recife, on stone wall; ca 80 m alt.; 3 7' $\mathrm{S}, 60^{\circ} 01^{\prime} \mathrm{W}, 8.7 .1988$, leg. Schäfer-Verwimp \& Verwimp 9781, conf. Sollman, as Barbula agraria (L). Paraíba: João Pessoa, Cabo Branco, on old stone wall of garden, $5 \mathrm{~m}$ alt., $7^{\circ} 09^{\prime} \mathrm{S}, 34^{\circ} 47^{\prime} \mathrm{W}, 12.7 .1990$, Schäfer-Verwimp \& Verwimp 12965 (G, STU). Pernambuco: Olinda near Recife, on stone wall, ca $40 \mathrm{~m}$ alt., 7.7.1986, Schäfer-Verwimp \& Verwimp 7195. Rio de Janeiro: Atlantic coast south of Rio de Janeiro city, Itacuruça, on stone wall of garden; $2 \mathrm{~m}$ alt., 14.8.1988, Schäfer-Verwimp \& Verwimp 9975. Rondônia: Porto Velho city, Hotel Floresta Negra, on stone wall; ca $85 \mathrm{~m}$ alt., 3.7.1988, SchäferVerwimp \& Verwimp 9710. Sergipe: São Cristovão, on old concrete wall in the center of the town, 30 m alt., 17.7.1987, Schäfer-Verwimp \& Verwimp 8749, det. Zander (BUF).

Distr.: Apparently a New World endemic: widespread in the Caribbean region, including the Gulf Coast of United States, eastern Mexico,
West Indies, Central America, and northeastern South America (Zander 1995). In Brazil previously known from Amazonas, Fernando de Noronha, Paraiba, Pernambuco, and Rio de Janeiro. New state records for Rondônia and Sergipe. Seems to be a rather widespread species in NE and $\mathrm{N}$ Brazil, but apparently rare at its southern limit in SE Brazil.

\section{Leptodontium stellatifolium (Hampe) Broth.}

Minas Gerais: Serra de Caparaó, on exposed rock in alpine vegetation on trail to Pico da Bandeira, 2820 m, 27.7.1987, leg. SchäferVerwimp \& Verwimp 8979, det. R. Zander (LAF); -, Serra de Itatiaia, road between Itamonte and Brejo da Lapa, on dripping rock, 1950 m, 2.4.1988, leg. Schäfer-Verwimp \& Verwimp 9567, det. R. Zander (LAF); -, Serra da Mantiqueira, Camanducaia, Monte Verde, campos-vegetation on top of Pedra Partida, on exposed rock, $2050 \mathrm{~m}$, 26.10.1990, leg. Schäfer-Verwimp \& Verwimp 13311 (EGR, STU). Santa Catarina: Serra do Rio do Rastro, Urubici, road to Morro da Igreja, on exposed rocks at $1750 \mathrm{~m}$ alt., 31.12.1990, leg. Schäfer-Verwimp \& Verwimp 13587; -, -, Nexposed rocks near the radar station beside the peak, together with Racomitrium didymum (Mont.) Lorentz in a gap at the edge on top of the rocks, 1780 m, 17.9.2001, leg M. Lüth 3596.

Distr.: This SE Brazilian endemic is known only from Rio de Janeiro and Espírito Santo. New to Minas Gerais and Santa Catarina.

\section{Lepyrodon tomentosus (Hook.) Mitt.}

Minas Gerais: Serra da Mantiqueira, Delfim Moreira, $22^{\circ} 35^{\prime} \mathrm{S}, 45^{\circ} 18^{\prime} \mathrm{W}$, pasture in forest near São Francisco dos Campos, epiphytic, 1560 m, 24.9.1988, leg. Schäfer-Verwimp \& Verwimp 9998 (SP); -, Camanducaia, Monte Verde, montane forest on trail to Chapéu do Bispo, epiphytic, 1820 m, 13.5.1990, leg. Schäfer-Verwimp \& Verwimp 12731; São Paulo: Serra da Bocaina near São José do Barreiro, montane forest, epiphytic, 1520 m, 18.4.1988, leg. Schäfer-Verwimp \& Verwimp 9642 (SP, STU).

Distr.: Widespread in the Americas from Mexico and Dominican Republic to Tierra del Fuego and SE- and S-Brazil (Allen 1999, with distribution map); new to Minas Gerais. 
Microlejeunea globosa (Spruce) Steph.

Espírito Santo: Domingos Martins, Reserva Florestal Pedra Azul, epiphytic in small remnant of secondary rain forest, c. per., $1240 \mathrm{~m}$, 2.7.1990, leg. Schäfer-Verwimp \& Verwimp 12858, det. Reiner-Drehwald.

Distr.: U.S.A., Mexico, Brazil, Paraguay, Argentina (detailed description, synonymy and distribution map in Reiner-Drehwald (1994); from Brazil known only from the states of São Paulo and Paraná; new to Espírito Santo.

Mnioloma nephrostipa (Spruce) R.M. Schust.

Minas Gerais: Santa Barbara, Serra de Caraça, trail to Morro Carapuza, on humid, earthcovered rock, 1550 m, 18.7.1989, leg. SchäferVerwimp \& Verwimp 11471.

Distr.: Hitherto known only from northern Amazonia and the Guyana Highlands; the find in Minas Gerais represents a remarkable outlying station.

\section{Odontoschisma longiflorum (Tayl.) Steph.}

Santa Catarina: Blumenau, Park Ecologico Spitzkopf, Pico Spitzkopf, cloud forest with low trees near the peak, epiphytic on a trunk of an old tree, together with Schlotheimia tecta Hook. \& Wils and Bazzania stolonifera (Sw.) Trev., 920 m, 14.9.2001, leg. M. Lüth 3574.

Distr.: Widespread in the West Indies and Northern South America, from Brazil known from Goias, Minas Gerais, Rio de Janeiro, and São Paulo, new to Santa Catarina and South Brazil.

\section{Paracromastigum pachyrhizum (Nees) Fulf.}

Santa Catarina: Serra do Corvo Branco, road Urubici - Grão Pará, near highest point on periodically wet rock, $1100 \mathrm{~m}$ alt., 30.12.1990, leg. Schäfer-Verwimp \& Verwimp 13508.

Distr.: Widely distributed in tropical America, from Brazil known from the states of Espírito Santo, Goias, Minas Gerais, Rio de Janeiro, and São Paulo (Gradstein \& Da Costa 2003, in press); new to Santa Catarina and South Brazil.

\section{Philonotis elongata (Dism.) Crum \& Steere}

Paraíba: Rocky slope on BR 230 (at km 120,5) between João Pessoa and Campina Grande,
$150 \mathrm{~m}, 13.7 .1990$, leg. Schäfer-Verwimp \& Verwimp 12970. Paraná: Lapa, ca. $70 \mathrm{~km}$ southwest of Curitiba, $25^{\circ} 47^{\prime} \mathrm{S}, 49^{\circ} 42^{\prime} \mathrm{W}$, humid secondary vegetation on Gruta do Monge, on dripping cliff, admixt to Distichophyllum sp., 950 m, 18.12.1991, leg. Schäfer-Verwimp \& Verwimp 15201/B. São Paulo: Serra da Bocaina E of Bananal, trail to Cachoeira do Mimosa, cloud forest near above the waterfall, on vertical furrow with loamy, sandy ground on the shady trail, $1120 \mathrm{~m}, 25.9 .2001$, leg. M. Lüth 3631.

Distr.: Mexico, Colombia, Ecuador, Peru, West Indies. First and single record for Brazil by Lisboa \& Yano (1987) from the state of Amazonas. New to NE, SE and S Brazil.

\section{Phyllodon truncatulus (Müll. Hal.) Buck}

Mato Grosso: Chapada dos Guimarães, canyon near waterfall Veu da Neuva, ca. $15^{\circ} 25^{\prime}$ $\mathrm{S}, 55^{\circ} 49^{\prime} \mathrm{W}$, on shady rock in forest, $500 \mathrm{~m}$, 5.7.1987, leg. Schäfer-Verwimp \& Verwimp 8626, det. Buck (NY). Minas Gerais: Poços de Caldas, Morro São Domingos, rain forest, on rock in brook, 1320 m, 24.5.1986, leg. Schäfer-Verwimp \& Verwimp 7026. Paraná: Sengés - Itararé, Gruta da Barreira on Rio Itararé, ca. $24^{\circ} 8^{\prime} \mathrm{S}, 49^{\circ} 21^{\prime} \mathrm{W}$, on shady dripping rock cliff, $620 \mathrm{~m}, 15.12 .1991$, leg. Schäfer-Verwimp \& Verwimp 15120. Santa Catarina: Blumenau, Park Floresta Negra, rain forest, on humid, shady rock, $200 \mathrm{~m}, 25.1 .1987$, leg. Schäfer-Verwimp \& Verwimp 8240, det. Buck (NY). São Paulo: Pico do Jaraguá near São Paulo City, rain forest, on periodically wet rock on brook, 810 m, 20.9.1987, leg. Schäfer-Verwimp \& Verwimp 9026, det. Buck (NY, STU); -, Ilha de São Sebastião, rain forest on Rio da Toca, on rock in brook, periodically submerged, $170 \mathrm{~m}, 11.2 .1990$, leg. Schäfer-Verwimp \& Verwimp 12503; -, -, on western slope, on shady rock, $470 \mathrm{~m}, 7.10 .1990$, leg. Schäfer-Verwimp \& Verwimp 13193; -, Serra do Mar near Ubatuba, Fazenda Capricornio, $23^{\circ}$ $24^{\prime} \mathrm{S}, 45^{\circ} 4^{\prime} \mathrm{W}$, primary rain forest on Rio Indaiá, on rotting wood, 120 m, 23.3.1989, leg. SchäferVerwimp \& Verwimp 10942; -, Serra de Paranapiacaba between Apiai and Iporanga, rain forest near Caverna Santana, in canyon forest on humid rock, $300 \mathrm{~m}, 1.5 .1987$, leg. SchäferVerwimp \& Verwimp 8434 (EGR, G, STU).

Distr.: Scattered in the Neotropics from the West Indies, Costa Rica to Peru, French 
Guiana; from Brazil known only from a very few 19th century collections from São Paulo (Yano 1981, as Glossadelphus) and from Santa Catarina (type of Hookeria obtusissima Müll. Hal., see Crosby et al. 1985) beside a recent record from Bahia (Vilas Bôas-Bastos \& Passos Bastos 2000) but probably overlooked; new to Mato Grosso, Minas Gerais, and Paraná.

\section{Squamidium diversicoma (Hampe) Broth.}

Paraná: Curitiba, Moretes, Estrada Graciosa, resting place Rio Cascata, epiphytic on isolated tree, together with Papillaria deppei (Hornsch.) Jaeg. and Pilotrichella flexilis (Hedw.) Ångstr., 820 m, 8.9.2001, leg. M. Lüth 3522 .

Distr.: Mexico, Honduras to southeastern Brazil (Allen \& Crosby 1986). New to Paraná.

\section{Syrrhopodon cryptocarpos Dozy \& Molk.}

São Paulo: Serra do Mar near Ubatuba, Fazenda Capricornio, primary lowland rainforest, at base of tree on Rio Indaià, $70 \mathrm{~m}$ alt., 26.9.1987,

Distr.: Widespread in Africa and tropical America, from Brazil known only from the Amazon basin (Acre, Amazonas, Pará, Rondônia) (Reese 1993, with distribution map); the record from São Paulo means a considerable range extension for this species in Brazil.

Syrrhopodon prolifer Schwaegr. var. cincinnatus (Hampe) Reese

Bahia: Chapada da Diamantina, rocky slope at roadside, on periodically wet rock, $800 \mathrm{~m}$ alt., 11.7.1987, leg. Schäfer-Verwimp \& Verwimp 8710 (STU).

Distr.: An uncommon taxon anywhere in its range from the West Indies, Central America, northern South America and disjunct in SE Brazil, in the state of São Paulo (Reese 1993, with distribution map); the record from Bahia closes the gap between Amazonas and São Paulo.

\section{Syrrhopodon rigidus Hook. \& Grev.}

São Paulo: Litoral Sul, Juréia near Peruibe, Praia do Arpoador, on dripping rock, $5 \mathrm{~m}$ alt.,
19.10.1990, leg. Schäfer-Verwimp \& Verwimp 13296(EGR, STU).

Distr.: Widespread in tropical America, from Brazil known only from the Amazon basin (Amapá, Amazonas, and Pará) (Reese 1993, with distribution map); the locality in São Paulo lies far away from the known distribution area.

\section{Zygodon obtusifolius Hook. [= Bryomaltaea obtusifolia (Hook.) Goffinet]}

São Paulo: Serra da Bocaina, Cunha, Sitio da Grama, $23^{\circ} 09^{\prime} \mathrm{S}, 44^{\circ} 50^{\prime} \mathrm{W}$, in pasture at base of old Araucaria angustifolia, 1380 m, c. spor., 28.5.1988, leg. Schäfer-Verwimp \& Verwimp 9664a (SP). Paraná: Guarapuava, pasture in forest on BR 277, epiphytic, $1170 \mathrm{~m}, 7.2 .1988$, leg. Schäfer-Verwimp \& Verwimp 9415 (SP). Minas Gerais: Serra da Mantiqueira, Delfim Moreira, on trunk of old Araucaria angustifolia near São Francisco dos Campos, c. spor., 1550 m, 24.9.1988, leg. Schäfer-Verwimp \& Verwimp 10030 (STU); -, -, Camanducaia, Monte Verde, in pasture at base of old Araucaria angustifolia, 1500 m, 12.5.1990, leg. Schäfer-Verwimp \& Verwimp 12702.

Distr.: Widespread from New Zealand, Tasmania, Asia, Africa and in America from Mexico to Patagonia; rarely collected in Brazil and known only from 19th century collections from Minas Gerais (Serra de Itatiaia) and Santa Catarina. New to São Paulo and Paraná.

\section{COSTA RICA}

\section{Aphanolejeunea clavatopapillata (Steph.)} Reiner

San José: Cordillera de Talamanca, valley of the Rio Chirripo Pacifico above San Gerardo de Rivas, epiphyllous on edge of rain forest along path to waterfall, $1600 \mathrm{~m}, 27.12 .1999$, leg. Schäfer-Verwimp \& Holz SV/H-0239/D, det T. Pócs.

Distr.: United States, Cuba, Argentina, Brazil, Paraguay; this is the second collection from Costa Rica and Central America (Dauphin et al. 1998). 
Aphanolejeunea microscopica (Taylor) A. Evans var. africana (Pócs) Pócs \& A. Lücking

San José: Cordillera de Talamanca, San Gerardo de Dota, epiphytic in humid secondary vegetation along Rio Savegre, 1900 m, 25.12.1999, leg. Schäfer-Verwimp \& Holz SV/H-0110, det. T. Pócs (INB); -, Cerro de la Muerte, km 84 of Transamericana, cloud forest, on Steereochila ecuadorica Inoue, 3220 m, 26.12.1999, leg. Schäfer-Verwimp \& Holz SV/H-0190/B, det. T. Pócs. Cartago: Cordillera de Talamanca, Reserva 3 de Junio, epiphytic on shrub, 2460 m, 3.1.2000, leg. Schäfer-Verwimp \& Holz SV/H-0448/C, det. T. Pócs.

Distr.: The var. africana is widely distributed in Africa and the Neotropics, but obviously hitherto not reported from Costa Rica.

\section{Aphanolejeunea minuta R.M. Schuster}

Limon: Park National Braulio Carillo, primary rain forest, epiphyllous, $500 \mathrm{~m}, 29.12 .1999$, leg. Schäfer-Verwimp \& Holz SV/H-0300/B, det. Pócs (EGR, GOET, INB, STU).

Distr.: Known only from Florida (Schuster 1980) and Colombia (Uribe \& Gradstein 1998) beside an unpublished record from Peru (Pócs in litt. 2003); new to Central America.

\section{Aphanolejeunea sintenisii (Steph.) Steph.}

San José: Cordillera de Talamanca, San Gerardo de Dota, primary forest „Los Robles“ with old Quercus copeyensis, on Porotrichum lancifrons, 2180 m, 4.1.2000, leg. Schäfer-Verwimp \& Holz SV/H-0470/B, det. T. Pócs.

Distr.: Azores, Madeira, otherwise widespread in the Neotropics (Grolle \& Long 2000); apparently hitherto not reported from Costa Rica.

\section{Cololejeunea bischleriana P. Tixier}

San José: Cordillera de Talamanca, San Gerardo de Dota, primary forest „Los Robles“ with old Quercus copeyensis, epiphyllous, 2200 m, 28.12.1999, leg. Schäfer-Verwimp \& Holz SV/ H-0273/C, det. T. Pócs (EGR, INB).

Distr.: Tropical America (Colombia, Brazil, Ecuador); new to Costa Rica.

\section{Lejeunea cancellata Nees \& Mont. in Mont.}

Cartago: Orosi valley, road to National

Park Tapanti, ca. $1 \mathrm{~km}$ before entrance, epiphytic on treelet along pasture, $600 \mathrm{~m}, 30.12 .1999$, leg. Schäfer-Verwimp \& Holz SV/H-0374/A, conf. M. E. Reiner-Drehwald (INB); San José: Cordillera de Talamanca, valley of the Rio Chirripo Pacifico above San Gerardo de Rivas, culture zone, epiphytic on tree along path to waterfall, $1600 \mathrm{~m}$, 27.12.1999, leg. Schäfer-Verwimp \& Holz SV/H0235/B(INB).

Distr.: Cuba, Florida, Argentina, Brazil, Surinam; fist record for Costa Rica by Holz et al. (2001); new to Cartago.

\section{Metalejeunea cucullata (Reinw. et al.) Grolle}

San José: Cordillera de Talamanca, San Gerardo de Dota, humid secondary vegetation on trail along Rio Savegre, epiphytic, mixed with Aphanolejeunea microscopica (Tayl.) Evans var. africana (Pócs) Pócs \& A. Lücking, 1900 m, 25.12.1999, leg. Schäfer-Verwimp \& Holz SV/H0110/A, det. T. Pócs (INB).

Distr.: Pantropical and known under many synonyms (Grolle 1995), but apparently not reported from Costa Rica.

\section{Hyophila nymaniana (Fleisch.) Menzel [=} Hyophila rosea Williams]

Guanacaste: Liberia, Park National Rincón de la Vieja, on rock beside brook, 750-800 $\mathrm{m}, 1.1 .2000$, leg. Schäfer-Verwimp \& Holz SV/H0395, det. P. Sollman (INB, L, STU).

Distr:: A primarily palaeotropical species known from India, Thailand to the Malay Peninsula and the Philippines (Eddy 1990, as Hyophila rosea Williams); firstly reported from the New World by Zander in Sharp et al. (1994, as H. rosea) from Mexico. New to Costa Rica.

\section{ECUADOR}

Diphyscium longifolium Griff. [= Diphyscium peruvianum Spruce ex Mitt.]

Zamora-Chinchipe: Podocarpus National Park at Rio Bombuscara ca $5 \mathrm{~km}$ south of Zamora, submontane rain forest, shady rock on edge of Rio Bombuscara, 1000 m, 19.4.2003, 
leg. Schäfer-Verwimp \& Preußing 23412 (LOJA, STU).

Distr.: Widespread throughout tropical Asia, Oceania, Central and South America (Magombo 2003, with distribution map). First record for Ecuador.

\section{Erpodium beccarii Müll. Hal. ex Vent.}

Loja: City centre of Loja, Plaza at church Santo Domingo, epiphytic in small quantity, associated with Orthotrichum diaphanum, 2100 m, 14.4.2003, leg. Schäfer-Verwimp 23260/B (LOJA).

Distr.: Widely distributed in Africa and tropical America, new to Ecuador.

Macrocolura sagittistipula (Spruce) R.M. Schust.

Zamora-Chinchipe: Podocarpus National Park at Rio Bombuscara ca $5 \mathrm{~km}$ south of Zamora, submontane rain forest, only a few plants epiphytic on old tree trunk, $1000 \mathrm{~m}$, 19.4.2003, leg. Schäfer-Verwimp \& Preußing 23396/B.

Distr.: Widespread in tropical America from Cuba and Puerto Rico to northern Amazonia, Colombia and Peru (detailed distribution, description and figures in Grolle \& Zhu 2002); new generic record for Ecuador.

\section{Marchantia berteroana Lehm. \& Lindenb.}

Zamora-Chinchipe: Rocky slopes on road Loja-Zamora, ca. km 10 - 11, on dripping cliff, 2720 m, 17.4.2003, leg. Schäfer-Verwimp \& Preußing 23342 (GOET, LOJA, STU).

Distr.: Widely distributed in the New World, South Africa, Indian Ocean Islands, and Oceania (see Bischler 1984); this is the first mainland record for Ecuador (known from Galapagos) which closes the wide gap between Colombia/Venezuela and Argentina/Chile.

Racomitrium subsecundum (Harv.) Wils. in Mitt. \& Wils.

Zamora-Chinchipe: Rocky slopes on road Loja - Zamora, ca. km 10 - 11, partially exposed to sunlight, $2740 \mathrm{~m}, 17.4 .2003$, leg. Schäfer-Verwimp \& Preußing 23338, det. H. Bednarek-Ochyra (KRAM, LOJA).
Distr.: Pantropical taxa, in South America known from Brazil, Colombia, Ecuador, Bolivia, and Venezuela (see above); new to ZamoraChinchipe.

\section{Radula eggersii Yamada}

Zamora-Chinchipe: Road Loja Zamora, km 10, humid shrubby vegetation at highest point „El Tiro“, on bracnch of shrub, 2780 m, 17.4.2003, leg. Schäfer-Verwimp \& Preußing 23330/A, det. K. Yamada (LOJA, STU, hb. Yamada).

Distr.: Recently described from Ecuador, Prov. de Loja, and hitherto known only from the type collection (Yamada 1997). New to ZamoraChinchipe.

Acknowledgments. For determination or confirmation of critical specimens we wish to thank $H$. Bednarek-Ochyra, Poland, W. R. Buck, U.S.A., the late H. Crum, U.S.A., C. Delgadillo, Mexico, J.-P. Frahm, Germany, H. Greven, The Netherlands, E. Maier, Switzerland, J. Muñoz, Spain, T. Pócs, Hungary, M. Price, Switzerland, P. Sollman, The Netherlands, M. E. ReinerDrehwald, Germany, and K. Yamada, Japan. the second author is grateful to Ing. Z. Aguirre (Loja, Ecuador) and N. Zamora (San José, Costa Rica), for their generous support in obtaining the necessary collecting and export permits, and the Deutsche Forschungsgemeinschaft supported field work in Ecuador.

\section{Literature}

Allen B. 1999. A revision of the moss genus Lepyrodon (Leucodontales, Lepyrodontaceae). Bryobrothera 5: 23-48.

Allen B. \& M.R. Crosby 1986. Revision of the genus Squamidium (Musci: Meteoriaceae). Journal of the Hattori Botanical Laboratory 61: 423476.

Bednarek-Ochyra H. 2001. New national and regional bryophyte records, 4. Racomitrium subsecundum (Hook. \& Grev. ex Harv. in Hook.) Wilson in Mitt. \& Wilson. Journal of Bryology 23(2): 151.

Bednarek-Ochyra H., Ochyra R. \& W.R. Buck 1999. The genus Racomitrium (Grimmiaceae) in Brazil, with the first report of $R$. subsecundum in South America. Brittonia 51(1): 93-105. 
Bischler H. 1984. Marchantia L. The New World Species. Bryophytorum Bibliotheca 26, 228 pp. J. Cramer, Berlin, Stuttgart.

Buck W.R. \& D.H. Norris 1996. Hedwigia stellata and $H$. detonsa (Hedwigiaceae) in North America. Nova Hedwigia 62: 361-370.

Churchill S.P., Griffin, D., III \& J. Muñoz 2000. A checklist of the mosses of the tropical Andean countries. Ruizia 17, 203 pp., Madrid.

Crosby M.R., Allen B.H. \& R.E. Magill 1985. A Review of the Moss Genus Hypnella. The Bryologist 88(2): 121-129.

Dauphin G., Gradstein S.R., Bernecker-Lücking A. \& M.I. Morales 1998. Additions to the hepatic flora of Costa Rica II. Lindbergia 23: $74-80$.

Eddy A. 1990. A Handbook of Malesian Mosses, vol. 2, 256 pp. Natural History Museum Publications, London.

Frahm J.-P. 1991. Dicranaceae: Campylopodioideae, Paraleucobryoi-deae. Flora Neotropica, Monograph 54, 239 pp., New York.

Gradstein S.R. \& D.P. da Costa 2003. Liverworts and Hornworts of Brazil. Memoirs of The New York Botanical Garden, vol. 87, New York.

Griffin D., III. 1984. Breutelia in Brazil with notes on the occurrence of the genus in the New World. Journal of the Hattori Botanical Laboratory 57: 83-95.

Griffin D., III. 1992. The distribution and synonyms of Breutelia microdonta (Mitt.) Broth. with additional notes on certain taxa of Breutelia. Tropical Bryology 5: 55-59.

Grolle R. 1995. The Hepaticae and Anthocerotae of the East African Islands. An Annotated Catalogue. Bryophytorum Bibliotheca 48, 178 pp. J. Cramer, Berlin, Stuttgart.

Grolle R. \& D.G. Long 2000. An annotated checklist of the Hepaticae and Anthocerotae of Europe and Macaronesia. Journal of Bryology 22: 103-140.

Grolle R. \& R.-L. Zhu 2002. On Macrocolura and the subdivision of Colura (Lejeuneaceae, Hepaticae). Journal of the Hattori Botanical Laboratory 92: 181-190.
Hedenäs L. 1994. The Hedwigia ciliata complex in Sweden, with notes on the occurrence of the taxa in Fennoscandia. Journal of Bryology 18: 139-157.

Holz I., Heinrichs J., Schäfer-Verwimp A. \& Gradstein S.R. 2001. Additions to the hepatic flora of Costa Rica III. Cryptogamie, Bryologie 22(4): 255-273.

Kuwahara Y. 1986. The Metzgeriaceae of the Neotropics. Bryophytorum Bibliotheca 28, 254 pp. J. Cramer, Berlin, Stuttgart.

Lisboa R.C.L. \& O. Yano 1987. Novas ocorrências de Briófitas na Amazônia brasileira. Boletim do Museu Paraense Emílio Goeldi, sér. Bot., 3(2): 141-156.

Magombo Z.L.K. 2003. Taxonomic revision of the moss family Diphysciaceae M. Fleisch. (Musci). Journal of the Hattori Botanical Laboratory 94: 1-86.

Muñoz J. 1999. A revision of Grimmia (Musci, Grimmiaceae) in the Americas. 1: Latin America. Annals of the Missouri Botanical Garden 86: 118-191.

Muñoz J. \& F. Pando 2000. A World Synopsis of the genus Grimmia (Musci, Grimmiaceae). Monographs in Systematic Botany, Missouri Botanical Garden 83, 133 p.

Reese W.D. 1993. Calymperaceae. Flora Neotropica Monograph 58, 102pp. The New York Botanical Garden, New York.

Reiner-Drehwald M.E. 1994. Sobre Microlejeunea globosa (Spruce) Steph. y la fragmentación del tallo, un tipo de reproducción asexual poco conocido en hepáticas. Candollea 49: $225-232$.

Schuster R.M. 1980. The Hepaticae and Anthocerotae of North America, Vol. IV, 1334 pp. Columbia University Press, New York.

Stone I.G. 1997. A revision of Erpodiaceae with particular reference to Australian taxa. Journal of Bryology 19: 485-502.

Uribe M., J. \& S.R. Gradstein 1998. Catalogue of the Hepaticae and Anthocerotae of Colombia. Bryophytorum Bibliotheca 53, 99pp. J. Cramer, Berlin, Stuttgart.

Vilas Bôas-Bastos S.B. \& C.J. Passos Bastos 2000. New Occurrences of Pleuro-carpous 
Mosses for the state of Bahia, Brazil. Tropical Bryology 18: 65-73.

Vital D.M. 1980. Erpodiaceae (Musci) do Brasil. Dissertação apresentada para a obtenção do grau de Mestre, Universidade Estadual Campinas.

Yamada K. 1997. Two new Radula species (Hepaticae; Radulaceae) from the Neotropica. Journal of the Hattori Botanical Laboratory 82: 337-342.

Yano O. 1981. A checklist of Brazilian Mosses. Journal of the Hattori Botanical Laboratory 50: $279-456$.

Yano O. 1995. A new additional annotated checklist of Brazilian Bryophytes. Journal of the Hattori Botanical Laboratory 78: 137-182.

Zander R.H. 1994. Hyophila, p. 270-273, in Sharp, Crum \& Eckel (edit.), The Moss Flora of Mexico. Memoirs of The New York Botanical Garden 69, 1113 pp., New York.

Zander R.H. 1995. Phylogenetic relationships of Hyophiladelphus gen. nov. (Pottiaceae, Musci) and a perspective on the cladistic method. The Bryologist 98(3): 363-374. 
